\title{
A Study on Environmental Effect of Electromagnetic Waves
}

\author{
Fidan Kaya Gülağız \\ Computer Engineering \\ Kocaeli University \\ İmit, 41380, Turkey
}

\author{
Furkan Göz \\ Computer Engineering \\ Kocaeli University \\ İmit, 41380, Turkey
}

\author{
Adnan Kavak \\ Computer Engineering \\ Kocaeli University \\ İmit, 41380, Turkey
}

\begin{abstract}
Electromagnetic waves play an important role in all areas of our life. Especially the use of radio, television and cellular systems that come out as a result of technological developments has expanded rapidly. For this reason the level of electromagnetic waves that people exposed has increased. Due to wide usage area of cellular system, the number of base stations has also increased. Electromagnetic waves emitted from the base stations have a negative impact on human health. The level of electromagnetic waves spread from radio, $\mathrm{TV}$ and other electronic tools that are used at home might go beyond the national and international limits. For this reason, electromagnetic boundary values have been determined by Turkey Telecommunication Authority (TTA) for in Turkey. The scope of this work, evaluation of electromagnetic wave spectrum located at Kocaeli University has been performed in terms of human health taking into account determined limit values. SPECTRA HF-4040 is used to measure electromagnetic field level. The frequency range of this device is among $100 \mathrm{MHz}$ and $4 \mathrm{GHz}$ and measuring level is among $90 \mathrm{dBm}$ and $0 \mathrm{dBm}$. The measurements of electromagnetic field limit have been tested in different locations of Umuttepe Campus in Kocaeli University. The different signal maps have been obtained for GSM 900, GSM 1800 and 3G frequencies. As a result of the measurements, it has been detected that electromagnetic waves do not exceed the limit of determined by TTA for Umuttepe and these waves do not cause electromagnetic field pollution at Umuttepe. Also, based on the signal levels, signal maps have created for Umuttepe and according to these signal levels we have obtained five different electromagnetic fields for campus. These fields have represented with different colors on the signal maps for different frequencies. In this manner, risky locations have been detected against to potential threads in the future.
\end{abstract}

\section{Keywords}

GSM, Electromagnetic Waves, Electromagnetic Pollution

\section{INTRODUCTION}

Magnetic field is the spaces in which kinetic and electrically charged particles are under influence of power and is formed following that electrons revolve around the nucleus and themselves. Magnetic field is a phenomenon which cannot be directly seen or easily felt, however its results can be seen and felt. Today, with the development of technology its measurement via devices has become possible. All substances are of magnetic fields, either living or non-living, weak or strong. Like every substance, there is a magnetic field of human beings, too. People are under the influence of their magnetic fields as well as the magnetic field of their surroundings naturally. Besides its advantages, this magnetic field might have disadvantages with the deformation of balance [1].
Today, among the electromagnetic field sources there are radars, mobile phones, radios and television transmitters, various instruments used in medical and industrial practices, high voltage power lines, microwave ovens and electrical home appliances. Among the electromagnetic fields sources, the radio frequency waves transmitted particularly from mobile phones and mobile phone base stations have been increasingly affecting the masses [2]. At the present time, considering the studies reporting that these waves have harmful effects on human health, it is seen that this issue has become a major health problem. People can be exposed to radio frequency waves in $900 \mathrm{MHz}$ frequency band emitted by mobile phones in two ways [3]. While radio frequency waves emitted by mobile phones affect only a portion of the body, particularly the head, waves emitted by base stations have an impact on the entire body. These waves are called radiation and they vary in terms of severity [4]. Similar to mobile phones, they transmit radiation in other devices that generate electromagnetic fields.

Radiation is the emission and the transmission of the energy in the form of electromagnetic waves or particles. As it is known, atoms compose the basic structure of the substance. It consists of a nucleus composed of atoms, protons and neutrons and electrons which revolve around it. If the number of neutrons in the nucleus of any substance is relatively more than the number of protons, these substances show an unstable structure and the neutrons in its nucleus are transformed and as a result they transmit $\beta$ - (negatron). If protons are more than neutrons, protons are transformed and as a result they transmit $\beta+$ (positron). The neurons and the protons separated from the atomic nucleus transmits unstable atomic nucleus gamma $(\gamma)$ ray. Heavy nuclei might transmit alpha $(\alpha)$ ray, namely helium nuclei, or can be exposed to fission reactions. The substances fragmented due to the exposure to these reactions are called "radioactive substance", while the rays transmitted to the environment such as alpha, beta and gamma are called "radiation" [5].

Radiation is divided into two groups according to the effect in substance; ionizing radiation and non-ionizing radiation. While the radiation whose radiation value is up to $300 \mathrm{GHz}$ is called as non-ionizing radiation, the radiation whose radiation value is above $300 \mathrm{GHz}$ radiation is called as ionizing radiation. Ionizing radiation can sever electron from atoms and molecules, however non-ionizing radiation does not have enough energy to break atomic bonds. On the other hand, nonionizing radiation is known to cause biological effects through heat, chemical reaction changes, the induction of electrical currents in cells and tissues [6]. So both type of radiation has impacts on human health. The purpose of this study is to analyze the effects of electromagnetic field radiation, thereby radiation levels for Kocaeli University. Thus, the areas that might pose a threat to human health in the campus will be determined. 
The rest of the study is organized as follows. In the second part, the effect of electromagnetic waves on human health is mentioned. In the third part, the previous experimental studies are included and in the last part, the results of the study are explained.

\section{EFFECTS OF ELECTROMAGNETIC WAVES}

The impact of electromagnetic waves on the natural life is being investigated for many years. The limit values of power of the waves emitted by electromagnetic field sources around us are determined by ICNIRP (International Commission on
Non- Ionizing Radiation Protection). If the value of the electromagnetic field around us exceeds these limit values, that will pose danger for living beings. Turkish Telecommunication Institution, based on the values set by the ICNIRP, has determined the limit values of electromagnetic field severity which are valid in Turkey. These values are demonstrated in Table 1 and Table 2. The concept of controlled exposure shown in Table 1, represents the people who are under the influence of electromagnetic fields due to their professions, while the concept of uncontrolled exposure in Table 2, represents the ones who are under the influence of electromagnetic fields due to their living environment.

Table 1: Limit values for the uncontrolled exposure in Turkey

\begin{tabular}{|c|c|c|c|c|c|}
\hline Frequency & \multicolumn{2}{|c|}{$\mathbf{9 0 0} \mathbf{M H z}$} & $\mathbf{1 8 0 0} \mathbf{M H z}$ & $\mathbf{2 2 0 0} \mathbf{M H z}$ \\
\hline & $\begin{array}{c}\text { Limit Values } \\
\text { for One Device }\end{array}$ & $\begin{array}{c}\text { Limit Values } \\
\text { for } \\
\text { Environment }\end{array}$ & $\begin{array}{c}\text { Limit Values } \\
\text { for One Device }\end{array}$ & $\begin{array}{c}\text { Limit Values } \\
\text { for } \\
\text { Environment }\end{array}$ & $\begin{array}{c}\text { Limit Values } \\
\text { for } \\
\text { Environment }\end{array}$ \\
\hline Electric Field Intensity & $10.23 \mathrm{~V} / \mathrm{m}$ & $41.25 \mathrm{~V} / \mathrm{m}$ & $14.47 \mathrm{~V} / \mathrm{m}$ & $58.34 \mathrm{~V} / \mathrm{m}$ & $61 \mathrm{~V} / \mathrm{m}$ \\
\hline Magnetic Field Intensity & $0.027 \mathrm{~A} / \mathrm{m}$ & $0.111 \mathrm{~A} / \mathrm{m}$ & $0.038 \mathrm{~A} / \mathrm{m}$ & $0.157 \mathrm{~A} / \mathrm{m}$ & $0.16 \mathrm{~A} / \mathrm{m}$ \\
\hline Power Density & $0.28 \mathrm{~W} / \mathrm{m}^{2}$ & $4.5 \mathrm{~W} / \mathrm{m}^{2}$ & $0.56 \mathrm{~W} / \mathrm{m}^{2}$ & $9.0 \mathrm{~W} / \mathrm{m}^{2}$ & $10 \mathrm{~W} / \mathrm{m}^{2}$ \\
\hline
\end{tabular}

Table 2: Limit values for the controlled exposure in Turkey

\begin{tabular}{|c|c|c|}
\hline Limits for 900 MHz & ICNIRP & IEEE/FCC \\
\hline Electric Field Intensity & $90.0 \mathrm{~V} / \mathrm{m}$ & - \\
\hline Magnetic Field Intensity & $0.24 \mathrm{~A} / \mathrm{m}$ & - \\
\hline Power Density & $22.5 \mathrm{~W} / \mathrm{m}^{2}$ & $30.0 \mathrm{~W} / \mathrm{m}^{2}$ \\
\hline Limits for 1800 MHz & ICNIRP & IEEE $/ \mathrm{FCC}$ \\
\hline Electric Field Intensity & $127.28 \mathrm{~V} / \mathrm{m}$ & - \\
\hline Magnetic Field Intensity & $0.34 \mathrm{~A} / \mathrm{m}$ & - \\
\hline Power Density & $45.0 \mathrm{~W} / \mathrm{m}^{2}$ & $50.0 \mathrm{~W} / \mathrm{m}^{2}$ \\
\hline
\end{tabular}

There are numerous published reports on the impact of electromagnetic fields on the health of living beings. Four of these reports have comprehensively dealt with this issue. In the first report published in 1989, the biological effects of electrical and magnetic fields have been argued [7]. On the other hand, in the second report published by EPA (Environmental Protection Agency) in 1990, the impact of electromagnetic fields on cancer diseases has been addressed [8]. In the report published in 1992 by CIRRPC (Interagency Committee on Radiation Research and Policy Coordination), it has been defended that there is no negative impact of electromagnetic fields on human health [9]. Finally, in the report published in 1996 by the National Academy of Sciences (NAS), the report prepared in 1992 has been given support and it has been defended that with the available data the damages of electromagnetic fields can't be confirmed [10]. In parallel with the reports mentioned, there are as much articles advocating that electromagnetic fields have an impact on human life as reports advocating the opposite. In spite of this, with the recent studies, the magnetic field has proven to have serious effects on the human body.

Kheifets et al. [11] has done a study showing that with the growth of technology electromagnetic radiation (EMR) takes much more part in our lives and that children encounter with EMR at a very young age. They have found out that the children encountering with electronic devices at a very early age will have more serious problems in the coming years due to radiation. They have mentioned that consequently the children's exposure to radiation will cause more permanent problems in the future as compared with adults. In a study conducted by Aggarwal and Gupta, the effects of electromagnetic waves on the human body have been investigated. In the study, it has been mentioned that the fact that the electromagnetic waves cause changes on the human genes or cell physiology could not be proved by the scientists. At the end of the research, it has been proven that electromagnetic waves kill the neurons and as a result it might cause some disorders such as stroke. It has also been mentioned that electromagnetic waves physiologically cause stress in the human body and absorb the proteins in the human body [12]. In a different review study, Aghaei et al. have made a research on the impact of EMR on human health. The study has stated that the effects of radiation are divided into two. These are listed as ionization and non-ionization. The most important finding obtained from the evaluation results is that all kinds of radiation particularly the radiation that is caused by micro waves make way for damages on human structure. The most notable ones of these damages are listed as nervous system disorders, heart diseases, immune system disorders, disorders of circadian rhythms, hormonal imbalances, changes in heart rate and blood pressure, etc. [13]. Taki has conducted a study in order to evaluate the potential health hazards brought along with the emerging technologies. In the study, especially the studies conducted by different researchers about the radiation formed by the use of mobile phones have been evaluated. Taki had mentioned before that the use of mobile phones might give rise to cancer and brain tumors, and that poses a risk has been determined by the limited sources, however, he has pointed out that these studies are not consistent with the rapidly developing technology and more research should be done in order to ensure people's safety in the field of EMR [14]. Akbal and 
Balık have evaluated the effects of electromagnetic waves on human health from a different perspective and have made a research on the antibacterial effects of electromagnetic waves. According to the results of experimental studies, it has been found out that electromagnetic waves prevent the growth of microorganisms.

Thus they have shown that, in addition to its negative impacts on human health, if electromagnetic waves are applied properly, they can be used in the treatment of some diseases [15]. In a report prepared by Lai in 2014, the genetically effects of non-ionizing electromagnetic fields have been investigated. Again in the same study, it has been claimed that $82 \%$ of the studies conducted until 2014 assert that electromagnetic field has an impact on genetics and $18 \%$ of the studies shows that electromagnetic field has no impact on genetic. When the studies are evaluated, it seems that the vast majority of these studies prove that electromagnetic field affects the genetics [16]. Again, a study was conducted in 2014 in order to avoid the effects of electromagnetic fields on human body. This study has discussed that electromagnetic radiation has a widespread and increasing influence over time, and that as a result it is necessary to prevent it [17].

Almost all the studies conducted so far have shown that electromagnetic waves affect the human health negatively. For this reason, the electromagnetic waves situated in the areas in which we live should remain in certain limits.

\section{EXPERIMENTAL RESULTS}

In this study, the measurement of electromagnetic field level in Umuttepe Campus of Kocaeli Universit was performed. Measurements were made at many different points inside the campus. Measurements were repeated for GSM 900, GSM 1800 and $3 \mathrm{G}$ frequencies and the signal maps belonging to each measurement were obtained. SPECTRA HF-4040 spectrum analyzer was used during the measurements. SPECTRA HF-4040 can measure between the range of 100 $\mathrm{MHz}$ and $4 \mathrm{GHz}$. Values obtained from the results of measurements were compared the electromagnetic field values determined by ICNIRP and evaluated in terms of human health.

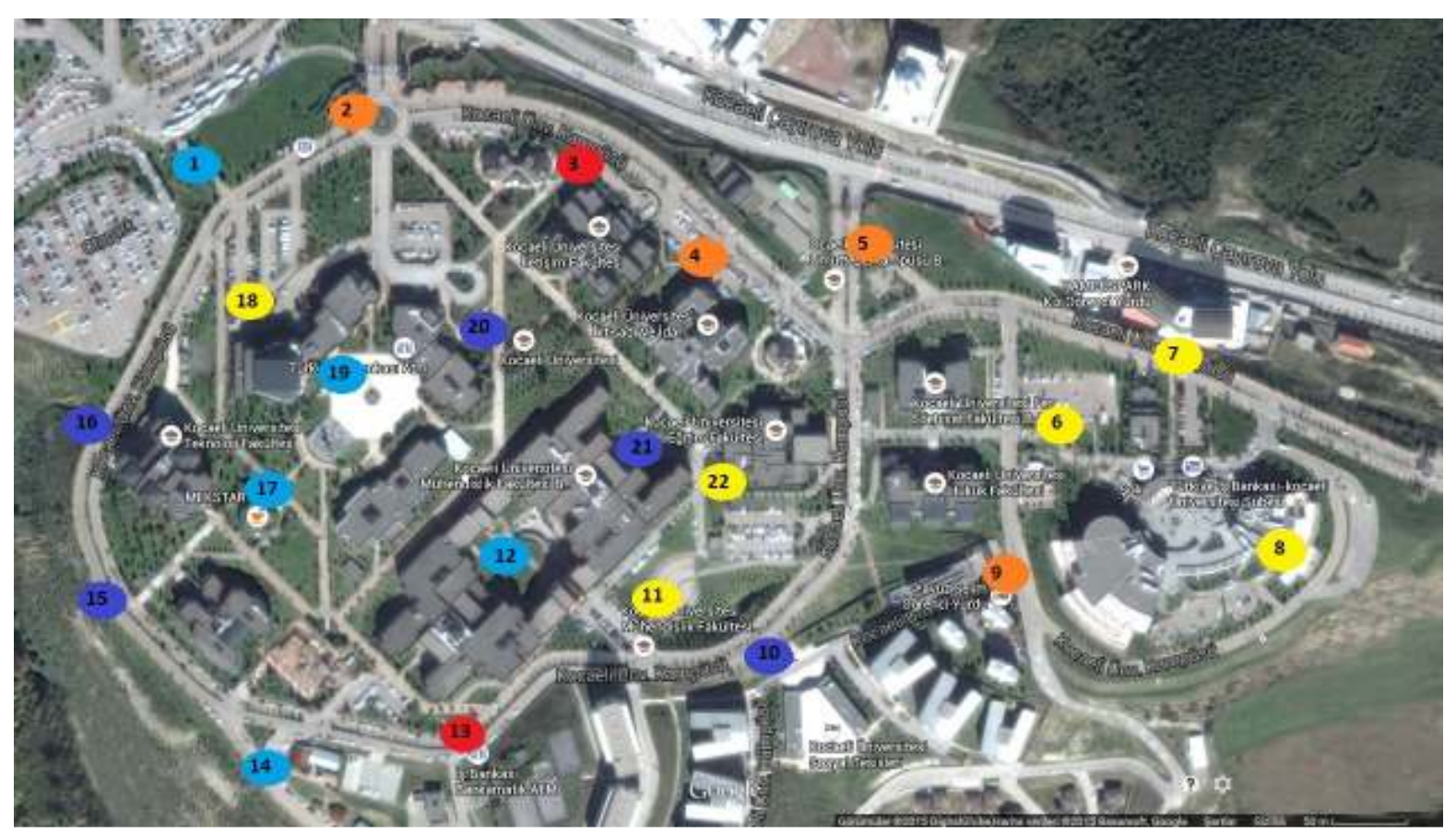

Figure 1: The signal map belonging to GSM 900 frequency

Table 3: The results of measurements belonging to GSM 900 frequency

\begin{tabular}{|c|c|c|c|c|}
\hline & \multicolumn{4}{|c|}{ GSM 900} \\
\hline Location & $\mathrm{dBm}$ & Wave Power Density $\left(\mathrm{W} / \mathrm{m}^{2}\right)$ & ICNIRP $(\mathrm{V} / \mathrm{m})$ & Frequency (f) \\
\hline 1 & -32 & $86.01 * 10^{-9}$ & 0.43 & 944 \\
\hline 2 & -23 & $576.2 * 10^{-9}$ & 1.1 & 948 \\
\hline 3 & -13 & $5.7 * 10^{-9}$ & 3.46 & 948 \\
\hline 4 & -20 & $1.13 * 10^{-9}$ & 1.54 & 948.8 \\
\hline 5 & -21 & $962.36 * 10^{-9}$ & 1.41 & 954.4 \\
\hline 6 & -28 & $196.63 * 10^{-9}$ & 0.64 & 949.6 \\
\hline 7 & -26 & $340.25 * 10^{-9}$ & 0.84 & 949.6 \\
\hline 8 & -27 & $264.8 * 10^{-9}$ & 0.74 & 950.4 \\
\hline 9 & -24 & $497.54 * 10^{-9}$ & 1.02 & 948.8 \\
\hline 10 & -40 & $11.08 * 10^{-9}$ & 0.15 & 935.2 \\
\hline 11 & -27 & $250.02 * 10^{-9}$ & 0.72 & 952 \\
\hline 12 & -33 & $68.59 * 10^{-9}$ & 0.37 & 949.6 \\
\hline 13 & -16 & $2.97 * 10^{-9}$ & 2.51 & 938.4 \\
\hline
\end{tabular}




\begin{tabular}{|c|c|c|c|c|}
\hline 14 & -34 & $45.86^{*} 10^{-9}$ & 0.31 & 935.2 \\
\hline 15 & -32 & $84.71 * 10^{-9}$ & 0.42 & 936.8 \\
\hline 16 & -43 & $6.85^{-9} 10^{-9}$ & 0.12 & 946.4 \\
\hline 17 & -32 & $80.9 * 10^{-9}$ & 0.41 & 934.4 \\
\hline 18 & -28 & $201.21 * 10^{-9}$ & 0.65 & 948 \\
\hline 19 & -31 & $95.8 * 10^{-9}$ & 0.44 & 949.6 \\
\hline 20 & -39 & $15.84 * 10^{-9}$ & 0.18 & 938.4 \\
\hline 21 & -46 & $3.04 * 10^{-9}$ & 0.08 & 946.4 \\
\hline 22 & -25 & $43.96^{*} 10^{-9}$ & 0.93 & 950.4 \\
\hline
\end{tabular}

The results of measurements in GSM 900 frequency are demonstrated in Table 3. In Figure 1 which is formed in accordance with the obtained data, for the values between -13 $\mathrm{dBm}$ and $-19 \mathrm{dBm}$ red, for the values between $-20 \mathrm{dBm}$ and $26 \mathrm{dBm}$ orange, for the values between $-27 \mathrm{dBm}$ and $-33 \mathrm{dBm}$ yellow, for the values between $-34 \mathrm{dBm}$ and $-39 \mathrm{dBm}$ light blue, and $-40 \mathrm{dBm}$ and lower signals dark blue colors are used. Considering the wave power density shown in Table 2 , for the systems running in $900 \mathrm{MHz}$, wave power density should be under $4.5 \mathrm{~W} / \mathrm{m}^{2}$ and among the values measured there is no value above $4.5 \mathrm{~W} / \mathrm{m}^{2}$. According to the regulations of ICTA (Information and Communication Technologies Authority), for $900 \mathrm{MHz}$, electrical area limit value per safety device in the base stations should not exceed $10.23 \mathrm{~V} / \mathrm{m}$. These values correspond to quadruple lower level of $41.25 \mathrm{~V} / \mathrm{m}$ which is set by ICNIRP and is the world standard taken as a reference by all the operators. In the result obtained for GSM 900, the wave power density and electrical field values are not above the specified limit.
The results of measurements in GSM 1800 frequency are demonstrated in Table 4. In Figure 2 which is formed in accordance with the obtained data, for the values between -29 $\mathrm{dBm}$ and $-35 \mathrm{dBm}$ red, for the values between $-36 \mathrm{dBm}$ and $41 \mathrm{dBm}$ orange, for the values between $-42 \mathrm{dBm}$ and $-47 \mathrm{dBm}$ yellow, for the values between $-48 \mathrm{dBm}$ and $-55 \mathrm{dBm}$ light blue, and $-56 \mathrm{dBm}$ and lower signals dark blue colors are used. Considering the wave power density shown in Table 2, for the systems running in $1800 \mathrm{MHz}$, wave power density should be under $9.0 \mathrm{~W} / \mathrm{m}^{2}$. Among the power density obtained from the measures there is no value above $9.0 \mathrm{~W} / \mathrm{m}^{2}$. In the case of evaluation for the electric field borders, similar results have been encountered as well. Electrical field limits are not exceeded at any point. When the GSM 900 frequency measurements are compared with the results of GSM 1800 frequency measurements, it has been determined that the wave power density values of the GSM 900 frequency are higher and it is closer to the electric field limit values.

Table 4: The results of measurements belonging to GSM 1800 frequency

\begin{tabular}{|c|c|c|c|c|}
\hline & & GSM & & \\
\hline Location & $\mathbf{d B m}$ & Wave Power Density $\left(\mathrm{W} / \mathrm{m}^{2}\right)$ & ICNIRP (V/m) & Frequency (f) \\
\hline 1 & -39 & $55.56^{*} 10^{-9}$ & 0.24 & 1810 \\
\hline 2 & -33 & $215.04 * 10^{-9}$ & 0.48 & 1806 \\
\hline 3 & -29 & $550.26 * 10^{-9}$ & 0.77 & 1808 \\
\hline 4 & -42 & $28.24 * 10^{-9}$ & 0.17 & 1808 \\
\hline 5 & -36 & $120.89 * 10^{-9}$ & 0.36 & 1808 \\
\hline 6 & -32 & $633.05 * 10^{-9}$ & 0.9 & 1808 \\
\hline 7 & -31 & $350.79 * 10^{-9}$ & 0.62 & 1808 \\
\hline 8 & -40 & $44.75 * 10^{-9}$ & 0.22 & 1811 \\
\hline 9 & -42 & $30.43 * 10^{-9}$ & 0.18 & 1811 \\
\hline 10 & -60 & - & - & - \\
\hline 11 & -42 & $32.16 * 10^{-9}$ & $0, .8$ & 1811 \\
\hline 12 & -48 & $7.27 * 10^{-9}$ & 0.08 & 1811 \\
\hline 13 & -29 & $340.12 * 10^{-9}$ & 0.75 & 1811 \\
\hline 14 & -48 & $7.37 * 10^{-9}$ & 0.08 & 1870 \\
\hline 15 & -36 & $127.83 * 10^{-9}$ & 0.37 & 1808 \\
\hline 16 & -39 & $55.09 * 10^{-9}$ & 0.24 & 1810 \\
\hline 17 & -41 & $39.54 * 10^{-9}$ & 0.2 & 1811 \\
\hline 18 & -42 & $30.98 * 10^{-9}$ & 0.18 & 1810 \\
\hline 19 & -56 & - & - & - \\
\hline 20 & -57 & - & - & - \\
\hline 21 & -56 & - & - & - \\
\hline 22 & -32 & $314.02 * 10^{-9}$ & 0.58 & 1811 \\
\hline
\end{tabular}




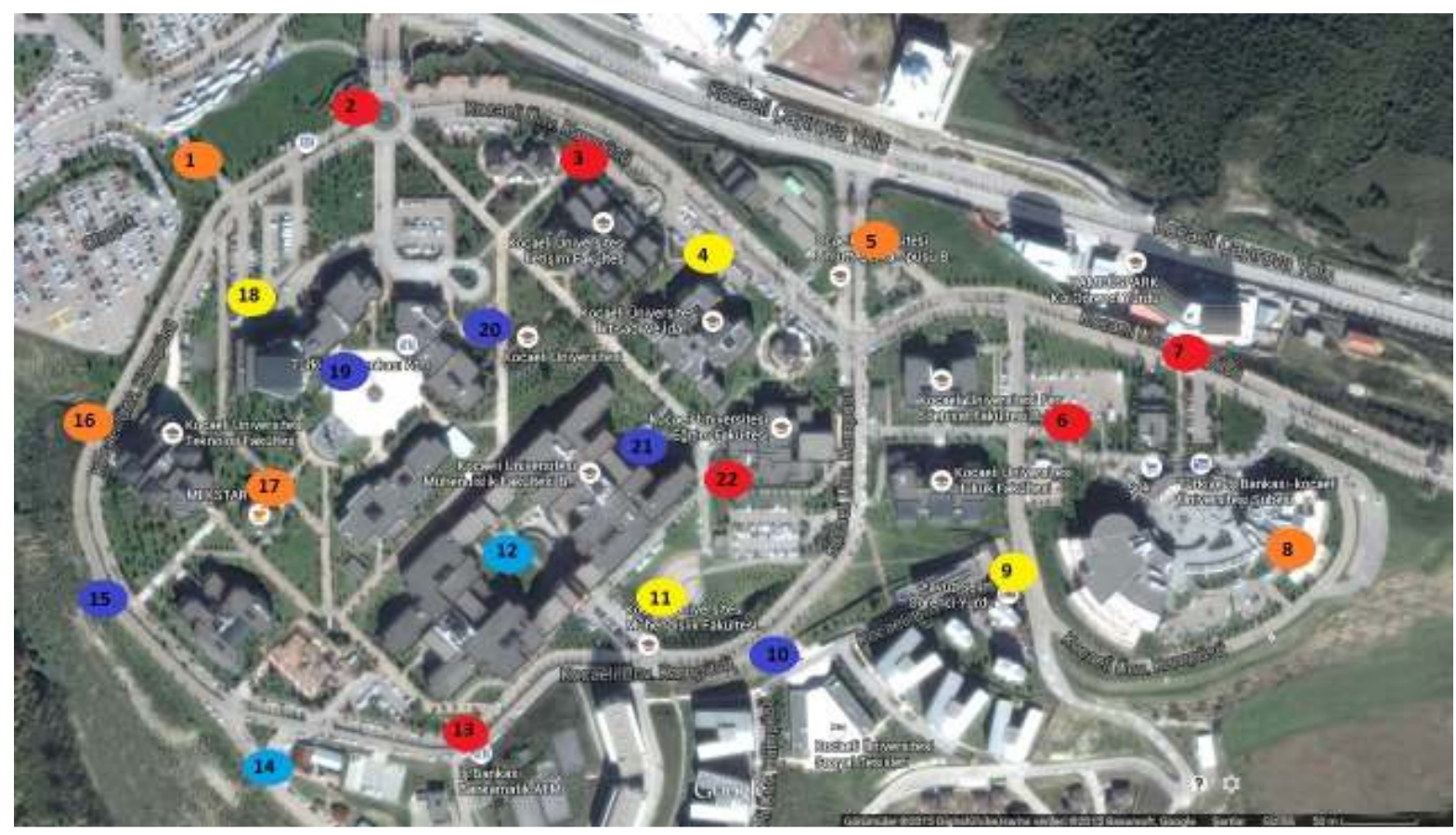

Figure 2: The signal map belonging to GSM 1800 frequency

The results of measurements in GSM 2200 frequency are demonstrated in Table 5. In Figure 3 which is formed in accordance with the obtained data, for the values between -29 $\mathrm{dBm}$ and $-33 \mathrm{dBm}$ red, for the values between $-34 \mathrm{dBm}$ and $38 \mathrm{dBm}$ orange, for the values between $-39 \mathrm{dBm}$ and $-44 \mathrm{dBm}$ yellow, for the values between $-45 \mathrm{dBm}$ and $-49 \mathrm{dBm}$ light blue, and $-50 \mathrm{dBm}$ and lower signals dark blue colors are used. Considering the wave power density shown in Table 2, for the systems running in $2200 \mathrm{MHz}$, wave power density should be under $10.0 \mathrm{~W} / \mathrm{m}^{2}$. Among the power density obtained from the measures there is no value above 10.0 $\mathrm{W} / \mathrm{m}^{2}$. When the electrical field values obtained from the measures are examined, it has been seen that the values did not exceed the limit value of $61 \mathrm{~V} / \mathrm{m}$.

Table 5: The results of measurements belonging to GSM 2200 frequency

\begin{tabular}{|c|c|c|c|c|}
\hline & \multicolumn{4}{|c|}{ GSM2200 (3G) } \\
\hline Location & $\mathbf{d B m}$ & Wave Power Density $\left(\mathbf{W} / \mathbf{m}^{2}\right)$ & $\begin{array}{c}\text { ICNIRP } \\
(\mathbf{V} / \mathbf{m})\end{array}$ & Frequency (f) \\
\hline 1 & -40 & $70.39 * 10^{-9}$ & 0.26 & 2122 \\
\hline 2 & -29 & $735.98 * 10^{-9}$ & 0.86 & 2153 \\
\hline 3 & -29 & $746.99^{*} 10^{-9}$ & 0.86 & 2153 \\
\hline 4 & -36 & $161.38^{*} 10^{-9}$ & 0.4 & 2138 \\
\hline 5 & -32 & $371.75^{*} 10^{-9}$ & 0.61 & 2133 \\
\hline 6 & -33 & $298.73 * 10^{-9}$ & 0.54 & 2147 \\
\hline 7 & -30 & $589.03 * 10^{-9}$ & 0.77 & 2153 \\
\hline 8 & -34 & $234.5 * 10^{-9}$ & 0.48 & 2152 \\
\hline 9 & -40 & $67.22^{*} 10^{-9}$ & 0.26 & 2132 \\
\hline 10 & -38 & $98.62 * 10^{-9}$ & 0.31 & 2114 \\
\hline 11 & -29 & $844.4 * 10^{-9}$ & 0.95 & 2132 \\
\hline 12 & -46 & $15.92 * 10^{-9}$ & 0.12 & 2152 \\
\hline 13 & -32 & $405.6^{*} 10^{-9}$ & 0.73 & 2118 \\
\hline 14 & -36 & $151.67 * 10^{-9}$ & 0.39 & 2118 \\
\hline 15 & -33 & $284.67 * 10^{-9}$ & 0.53 & 2122 \\
\hline 16 & -39 & $77.48^{*} 10^{-9}$ & 0.28 & 2117 \\
\hline 17 & -39 & $75.2 * 10^{-9}$ & 0.27 & 2127 \\
\hline 18 & -39 & $82.3 * 10^{-9}$ & 0.28 & 2122 \\
\hline 19 & -39 & $74.08^{*} 10^{-9}$ & 0.27 & 2132 \\
\hline 20 & -46 & $16.62 * 10^{-9}$ & 0.12 & 2117 \\
\hline 21 & -51 & $6.45 * 10^{-9}$ & 0.08 & 2133 \\
\hline 22 & -22 & $4.14^{*} 10^{-9}$ & 2.04 & 2122 \\
\hline
\end{tabular}




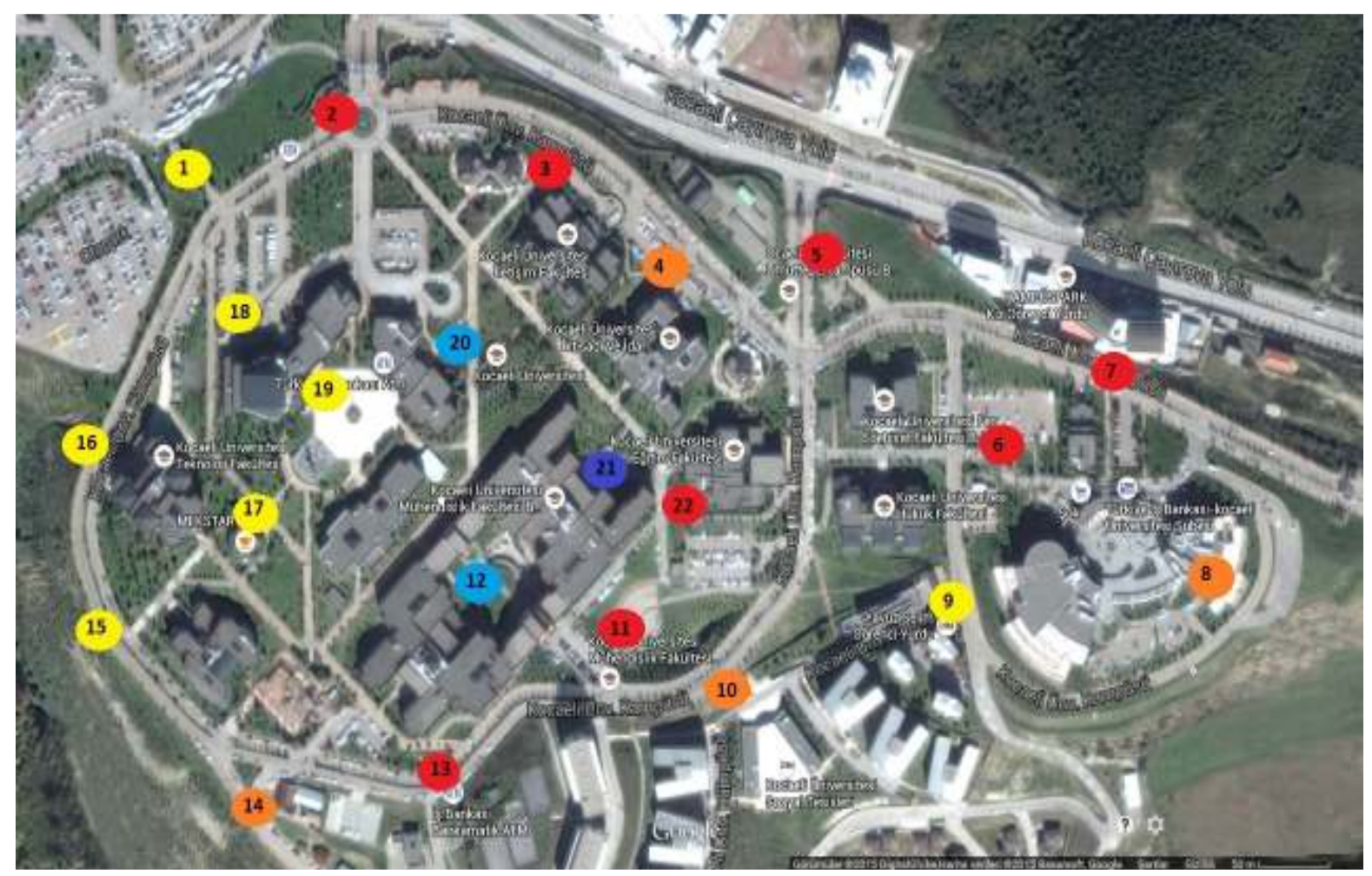

Figure 3: The signal map belonging to GSM 2200 frequency

\section{CONCLUSION}

Thoughts about the negative impact of base stations on the human health and environment have increased with the growing number of base stations established for cellular systems which are technological needs. However, it has been understood that when the limits set by international organizations are applied, the impact of the base station could be reduced.

In this study, electromagnetic field level generated by base stations in different points of Umuttepe Campus of Kocaeli University has been evaluated. The results of the evaluations have shown that for GSM 900, GSM 1800 and 3G frequencies, there is not any electromagnetic field density that may pose a risk to human health and the environment at any point in the campus. In fact, the values obtained from the measures were substantially lower than the limit values set by ICNIRP. Thus it has been determined that the base stations are placed conscious and within the legal limits.

\section{ACKNOWLEDGMENTS}

Our thanks to the undergraduate students Enes Köksal and Yakup Albayrak who have contributed towards the measurements of signal levels and obtaining signal maps.

\section{REFERENCES}

[1] Bold, A., Toros, H., Şen O. 2003. Manyetik alanın insan sağlığı üzerindeki etkisi. In Proceedings of the III. Atmosfer Bilimleri Sempozyumu, 62-68.

[2] Şeker, S. and Çerezci, O. 2000. Radyasyon Kuşatması: Elektriğin ve Nükleer Enerjinin Sağlığımıza Etkileri. Boğaziçi Üniversitesi Yayınevi.

[3] Özgüner, F. and Mollaoğlu, H, "Manyetik alanın organizma üzerindeki biyolojik etkileri”, S.D.Ü. Tıp Fakültesi Dergisi, 2006.
[4] Hayland, G.J, “Physics and biology of mobile telephony”, Lancet, 2000.

[5] Sarıkahya, N. M. 2014.Bir İşyerinde Elektromanyetik Alan Ölçümü Yapılması ve Sonuçlarının İș Sağlığı ve Güvenliği Yönünden Değerlendirilmesi. Master Thesis. T.C. Çalışma ve Sosyal Güvenlik Bakanlığı.

[6] Türkkan, A. and Pala, K, "Çok düşük frekanslı elektromanyetik radyasyon ve sağlik etkileri”, Uludağ Üniversitesi Mühendislik-Mimarlık Fakültesi Dergisi,2009.

[7] Office of Technology Assessment (O.T.A.). (1989). Biological effects of power frequency electric \& magnetic fields-Background paper, OTA-BP-E53.Washington, DC: U.S. Government Printing Office.

[8] Environmental Protection Agency (EPA). 1990Evaluation of the Potential Carcinogenicity of Electromagnetic Fields, Washington, D.C.

[9] CIRRPC. 1992Health Effect of Low-Frequency Electric and Magnetic Fields, Report No: ORAU 92/F8, Committee on Interagency Radiation Research and Policy Coordination, Oak Ridge Associated Universities. Knoxville, Tennessee: ORAU.

[10] National Academy of Science. 1996. Possible Health Effects of Exposure to Residential Electric and Magnetic Fields. Washington, DC: National Academy Press.

[11] Kheifets, L., Repacholi, M., Saunders, R., Deventer, E, "The sensitivity of children to electromagnetic fields", Pediatrics, 2005.

[12] Aggarwal, A. and Gupta, A. 2011. Effect of electromagnetic radiations on humans: a study. In 
Proceedings of the IEEE Students' Technology Symposium, 75-80.

[13] Aghaei, M., Thayoob, Y. H. M., Mahdaviasl, S., Darzi, S. 2012. A review on the impact of the electromagnetic radiation on the human's health. In Proceedings of the National Graduate Conference.

[14] Taki, M. 2013. Assessment of possible health risks of electromagnetic field exposures due to emerging technologies. In Proceedings of the International Symposium on Electromagnetic Theory.
[15] Akbal, A. andBalık, H. H, "Investigation of antibacterial effects of electromagnetic waves emitted by mobile phones", Polish Journal of Environmental Studies, 2013.

[16] Lai, H. 2014Genetic Effects of Non-Ionizing Electromagnetic Fields, The Bioinitiative Report, Section 6.

[17] Bhattacharjee, S, "Protective measures to minimize the electromagnetic radiation", Advance in Electronic and Electric Engineering, 2014. 